\title{
The Effect of Need for Achievement, Locus of Control and Attitudes towards Student Entrepreneurial Intentions in SMKN 1 Batang Hari
}

\author{
Herry Sofyandy Pranata $^{1 *}$; Khairinal²; Denny Denmar ${ }^{3}$ \\ ${ }^{1,2,3}$ Department of Economics Education, Graduate Program, University of Jambi \\ Jl. Raya Jambi - Muara Bulian No. Km. 15, Mendalo Darat, Jambi 36122, Indonesia \\ 'herrysofyabdy@gmail.com; 2khairinal@unja.ac.id; ${ }^{3}$ Dennydenmar@unja.ac.id
}

Received: $23^{\text {rd }}$ January 2021/ Revised: $06^{\text {th }}$ March 2021/ Accepted: $12^{\text {th }}$ March 2021

\begin{abstract}
How to Cite: Pranata, H. S., Khairinal., \& Denmar, D. (2021). The effect of need for achievement, locus of control, and attitudes towards student entrepreneurial intentions in SMKN 1 Batang Hari. The Winners, 22(1), 39-45.

https://doi.org/10.21512/tw.v22i1.6987
\end{abstract}

\begin{abstract}
High unemployment rate, especially from SMK graduates, and the lack of entrepreneurship in Indonesia have prompted many parties to find out solutions. It is very important in fostering graduates who are ready to become entrepreneurs. The research aimed to investigate the influence of need for achievement, locus of control, and attitudes toward entrepreneurial intentions of students of SMK Negeri 1 Batang Hari. Data analysis method used path analysis in which multiple regression models were tested with classical assumptions to determine the appropriate analysis model. The classical assumption test included: normality test using the one-sample Kolmogorov-Smirnov test, homoscedasticity test using the Spearman's Rho test, and linearity test using the lack of fit test and the multicollinearity test. With a sample of 175 class-XI students of all majors at SMKN 1 Batang Hari, the result shows that there is an influence of need for achievement, locus of control, and attitudes toward students' entrepreneurial intention at SMK Negeri 1 Batang Hari.
\end{abstract}

Keywords: need for achievement, locus of control, locus of attitudes, entrepreneurial intention

\section{INTRODUCTION}

Indonesia has the largest population, placed in the world's fourth rank after China, India, and America. The Ministry of Home Affairs through the Directorate General of Population and Civil Registration has released Indonesian population data based on data for the first semester of January 2020. The total population of Indonesia as of 30 June is 268.583.016. Indonesia has a large population, so the country needs a large workforce to support its economic activities.

In fact, according to data released by Badan Pusat Statistik (Statistics Indonesia) as of February 2020 , regarding the open unemployment rate based on the highest education completed, Vocational High School (SMK) graduates experienced the most unemployment reaching $8,49 \%$. An elementary school graduate has unemployment reaching 2,64\%, while junior high school graduates experience an unemployment rate of $5,02 \%$. High school graduates experience an unemployment rate of $6,77 \%$. Diploma and University graduates reached $6,76 \%$ and $5,73 \%$. The slowdown in Indonesia's economy is seen as a factor in the increasing number of domestic unemployment. This unemployment rate is dominated by academic unemployment.

The high unemployment rate and the lack of entrepreneurship in Indonesia have prompted many parties to find solutions. Unemployment is a complex problem as it causes poverty, crime, declining health and low education. Vocational High School (Sekolah Menengah Kejuruan/SMK) is a formal school under the Ministry of Education and Culture of the Republic of Indonesia which aims to train graduates who are ready to work independently as entrepreneurs. Considering the average age of students in the production stage who want to receive science and technology including entrepreneurship, it is very important in fostering graduates of vocational schools who are ready to become entrepreneurs.

The Ministry of National Education states that one of the efforts made by the government to create jobs is through an entrepreneurial encouragement. Meanwhile, according to Rahayu (2018), entrepreneurial intention is an individual's intention to take entrepreneurial actions and develop 
their business. Intentions play a unique role in guiding actions, linking deep thoughts that people believe and want with specific actions (Wijaya et al., 2015). Learning entrepreneurship in vocational high school can foster entrepreneurial intentions. The entrepreneurial encouragement that is formed is expected to increase the entrepreneurial intention of students. The development of entrepreneurial attitudes of vocational school students needs to be supported by skills that prioritize work skills, independence and entrepreneurship so they are able to professionally compete in real jobs. Vocational school students must have a strong desire to become entrepreneurs, which will have an impact on opening up more job opportunities. All students from class XI to class XII can take part in entrepreneurship learning at vocational school with the hope that the entrepreneurial encouragement is established through learning.

SMK Negeri 1 Batang Hari is one of the vocational schools in Batang Hari with six expertise programs, namely the Expertise Program in Accounting, Multimedia, Marketing, Catering, Computer Engineering, and offices to foster students' entrepreneurial encouragement by organizing entrepreneurship learning through classroom learning and entrepreneurial practice. Students at SMK Negeri 1 Batang Hari are introduced and taught entrepreneurship training from class XI to class XII. They are given the opportunity to carry out entrepreneurial activities through school cooperatives and sales practices individually or in groups so that the learning activities are expected to form entrepreneurial intentions after graduation. In fact, what happens is that the learning activities only form the mindset to get jobs at companies, not to create their own jobs.

It happens because during the internship practice at SMK Negeri 1, students are assigned to work at retail stores, not Small and Medium Enterprises (SMEs). Entrepreneurship is an effective way to overcome the imbalance between the workforce and the available jobs. However, the current entrepreneurial intention of SMK Negeri 1 Batang Hari students occurs to be low. In the initial survey conducted on 30 class XI students of SMKN 1 Batang Hari, it is known that there are only three students who want to become entrepreneurs after graduating, while 20 students plan to go to college and seven other students want to apply for jobs. Therefore, entrepreneurship education cannot be considered as an absolute guarantee that a student will establish a business.

Chrismardani (2016) states that behavioral attitudes are the basis for forming intentions. Ma'rifah (2019) points out that entrepreneurial attitude is an aspect that must be shaped in the educational process to determine future careers. An entrepreneurial attitude allows one to see opportunities, have responsibility and have the courage to make all decisions. The indicators that determine a person's entrepreneurial attitude are: (1) interest in business opportunities; (2) creative thinking, (3) positive attitude towards business failure, (4) leadership skills and a sense of responsibility, and
(5) ability to deal with risks and challenges.

Intention is influenced by several factors, including need for achievement and locus of control. These two factors are both psychological driving factors and strong characteristics known as factors that influence entrepreneurial behavior. Need for achievement is a strong urge or desire from individuals to carry out tasks in accordance with predetermined success criteria (Ermawati, Soesilowati, \& Prasetyo, 2017).

Untu and Widjaja (2019) find out that need for achievement is a positive predictor of entrepreneurial intention. Similarly, Handaru, Parimita, and Mufdhalifah (2015) come up with a result where the need for achievement variable shows a t-count of 2,104 and a significance value of 0,038 . This shows that $\mathrm{t}$-count $>\mathrm{t}$-table and the significance value is smaller than 0,05. That is, $\mathrm{H}_{0}$ is rejected and $\mathrm{H}_{\mathrm{a}}$ is accepted. Thus, need for achievement has a positive and significant effect on entrepreneurial intentions.

Locus of control is one of the personality variables, which is defined as an individual's belief in their ability to control their own destiny (Musdalifah \& Baharuddin, 2015). Murni (2017) finds that there is a positive relationship between internal locus of control and entrepreneurial intentions, where the p-value of 0,000 is smaller than 0,05 indicating that the relationship between internal locus of control and entrepreneurial intention is significant. Higher internal locus of control leads to a higher entrepreneurial intention, and vice versa. Blegur and Handoyo (2020) obtain similar result showing that $t$-statistical value is 5,054 and p-value is 0,000 , which means that locus of control has a positive and significant effect on entrepreneurial intentions.

The problems examined in the research are: (1) Does need for achievement affect students' entrepreneurial attitudes in SMKN 1 Batang Hari? (2) Does locus of control affect students' entrepreneurial attitudes in SMKN 1 Batang Hari? (3) Does need for achievement have a direct effect on students' entrepreneurial intentions in SMKN 1 Batang Hari? (4) Does locus of control have a direct effect on students' entrepreneurial intentions in SMKN 1 Batang Hari? (5) Does the entrepreneurial attitude affect the students' entrepreneurial intention in SMKN 1 Batang Hari? (6) Does need for achievement by mediating entrepreneurial attitudes have an effect about students' entrepreneurial intentions in SMKN 1 Batang Hari? (7) Does the locus of control with the mediation of entrepreneurial attitudes affect the students' entrepreneurial intention in SMKN 1 Batang Hari?

\section{METHODS}

This is a quantitative research, in which the methods are based on a specific population or sample collected using research tools. Data analysis is quantitative or statistical in nature, with the aim 
of testing predetermined hypotheses to test specific populations and samples, and analyze the statistical data (Fitria \& Sudarmadi, 2019; Aulia \& Yulianti, 2019). The population in the research are 313 students of class XI at SMKN 1 Batang Hari. There are 175 students taken as research subjects using purposive sampling technique with certain considerations. The instrument measurement scale uses a Likert scale with five levels: (1) score of 5 for 'strongly agree', (2) score of 4 for 'agree', (3) score of 3 for 'doubt/ neutral', (4) score of 2 for 'disagree', and (5) score of 1 for 'strongly disagree'.

Data collection method is a technique to collect data which will be used to obtain material and information related to the research (Imron, 2019). The research uses an online questionnaire through google forms distributed to students of class XI in SMKN 1 Batang Hari by first being tested on a research trial sample to determine its validity and reliability.

Purposive sampling technique is used to determine the sample in each class. The criteria for respondents are: 1) classes that have implemented the entrepreneurship course curriculum, 2) students who have studied entrepreneurship, and 3) students who have graduated studying entrepreneurship. There are nine classes at SMKN 1 Batang Hari, which are Accounting 1, Accounting 2, Multimedia, Marketing 1, Marketing 2, Catering, Computer and Network Engineering, Office 1 and Office 2.

To determine the number of samples according to the existing criteria, the following formula is used:

$n i=\frac{N i}{N} \times n$

Information:

ni $=$ number of samples according to strata

$\mathrm{n} \quad=$ total population

$\mathrm{Ni}=$ total population according to strata

$\mathrm{N}=$ total sample size

Based on the formula, the calculation of sample proportion from representatives of each study program is shown in Table 1.

Table 1 Calculation of Sample Proportion from Representatives of Each Study Program

\begin{tabular}{lccc}
\hline \multicolumn{1}{c}{ Study Program } & $\begin{array}{c}\text { Total } \\
\text { Students }\end{array}$ & $\begin{array}{c}\text { Calculation } \\
\text { of Amount }\end{array}$ & Samples \\
\hline Accounting & 70 & $70 / 313 \times 175$ & 39 \\
Multimedia & 34 & $34 / 313 \times 175$ & 19 \\
Marketing & 70 & $70 / 313 \times 175$ & 39 \\
Cullinary art & 34 & $34 / 313 \times 175$ & 19 \\
Computer & 35 & $35 / 313 \times 175$ & 20 \\
and Network & & & \\
Engineering & & & \\
Offices & 70 & $70 / 315 \times 176$ & 39 \\
\hline Total & & & 175 \\
\hline
\end{tabular}

The validity test is performed using the Pearson Product-Moment Correlation test. If the correlation results with the total score of each variable $\geq 0,30$, the instrument is declared valid. Reliability test is conducted using Cronbach Alpha. If the Alpha value is $\geq 0,70$, it is said to be reliable.

Path analysis is an extension of multiple linear regression analysis. Path analysis uses regression analysis to estimate causal relationships between predetermined variables based on theory (accidental models) aiming to know the direct or indirect effect of a set of independent variables on the dependent variable (Arifin, 2018). According to Patanduk et al. (2019), direct effect is the effect of one independent variable on the dependent variable without going through other variables. The direct and indirect effects can be seen as: 1) Direct effect is the results of X1 X2 and $X 3$ against $Y$, and 2 ) Indirect Effect is the indirect result, where $\mathrm{X}$ is against $\mathrm{Y}$. The equation is provided:

Sub-Structure 1:

$\mathrm{Z}=\mathrm{a} 1+\beta 1 \mathrm{X} 1+\beta 2 \mathrm{X} 2+\mathrm{e}$

Sub-Structure 2:

$\mathrm{Y}=\mathrm{a} 2+\beta 1 \mathrm{X} 1+\beta 2 \mathrm{X} 2+\beta 3 \mathrm{Z}+\mathrm{e}$

Where:

$\begin{array}{ll}\mathrm{X} 1 & =\text { Need for achievement, } \\ \mathrm{X} 2 & =\text { Locus of control, } \\ \mathrm{Z} & =\text { Entrepreneurial attitude } \\ \mathrm{Y} & =\text { Entrepreneurial intention. } \\ \alpha 1, \alpha 2 & =\text { constant; } \\ \beta 1, \beta 2, \beta 3 & =\text { regression coefficient } \\ \mathrm{e} & =\text { error. } \mathrm{Z}\end{array}$

These are the intervening variables to determine the effect of need for achievement, locus of control indirectly on employee performance. To test the effect of the intervening variables, the path analysis method is used.

Multiple regression models must be tested with classical assumptions to determine the appropriate analysis model. The classical assumption test includes: 1) Normality test using the One-Sample Kolmogorov-Smirnov test, 2) Homoscedasticity test using the Spearman's Rho test, and 3) Linearity test using the lack-of-fit test and the multicollinearity test by looking at the tolerance or Variance Inflation Factor (VIF) results.

If the tolerance is greater than 0,10 or the VIF is less than 10 , multicollinearity does not occur. To simplify the analysis, the research uses a multi-variate analysis application with the IBM SPSS 21.0.

\section{RESULTS AND DISCUSSIONS}

The validity of the instrument based on the Pearson Product-Moment correlation test shows that the need for achievement variable consisting of 11 questions, locus of control consisting of 11 questions, entrepreneurial attitude with 9 questions and 
entrepreneurial intention with 9 questions are declared valid all of them since the correlation coefficients are all above 0,30.

Meanwhile, the reliability test results show that: 1) the need for achievement instrument is 0,891 with $\mathrm{N}$ of 11 items, 2) locus of control is 0,935 with $\mathrm{N}$ of 11 items, 3) entrepreneurial attitude is 0,908 with $\mathrm{N}$ of 9 items, and 4) entrepreneurial intention is 0,917 with $\mathrm{N}$ of 9 items. Therefore, all Cronbach Alpha values are greater than 0,70 which indicates that the need for achievement, locus of control, entrepreneurial attitude, and entrepreneurial intention are all reliable.

As seen in Table 2, the classical assumption test based on the output of SPSS 21 with one-sample Kolmogorov-Smirnov test shows that the Sig. is greater than 0,05 , thus it occurs that the need for achievement variable, locus of control variable, entrepreneurial attitude and entrepreneurial intention variables are normally distributed.

Table 2 Data Normality Test Results

\begin{tabular}{llr}
\hline & & \multicolumn{2}{c}{$\begin{array}{c}\text { Unstandardized } \\
\text { Residual }\end{array}$} \\
\hline $\mathrm{N}$ & & 175 \\
Normal Parameters & & \\
& Mean & 0,0000000 \\
& Std. Deviation & 1,52300835 \\
Most Extreme & Absolute & 0,067 \\
Differences & Positive & 0,067 \\
Test Statistic & & 0,67 \\
Asymp.sig.(2-tailed) & & $0,200^{\mathrm{c}}$ \\
\hline
\end{tabular}

a. Test distribution is Normal

b. Calculated from data

c. Lilliefors Significance Correction.
The relationship between need for achievement, locus of control, and entrepreneurial attitudes towards entrepreneurial intentions is linear. The lack-of-fit test finds that the Sig. of need for achievement is 0,223 , locus of control is 0,988 , the entrepreneurial attitude is 0,574 . They are all greater than 0,05 . The output of SPSS 25 is shown in Table 3.

Table 3 Linearity Test Results

\begin{tabular}{lcc}
\hline \multicolumn{1}{c}{ Variabel } & \multicolumn{1}{c}{ Explanation } & Sig. \\
\hline Need for & Deviation from Linearity & 0,233 \\
Achievement & & \\
Locus of Control & Deviation from Linearity & 0,988 \\
Entrepreneurial & Deviation from Linearity & 0,574 \\
Attitude & & \\
\hline
\end{tabular}

The multicollinearity test results in Table 4 do not show multicollinearity since the tolerance results are all greater than 0,10 . Besides, the VIF results are all smaller than 10, as shown in Table 5. Based on the results of the SPSS 25 output, the regression equation can be determined as:

$$
\begin{aligned}
& Y=0,269 X 1+0,525 X 2+\mathrm{e} \\
& Z=0,236 X 1+0,484 X 2+0,212 Y
\end{aligned}
$$

Therefore, the path coefficient, the indirect effect, and the total effect can be summarized as shown in Table 5 .

First, the discussion starts with the influence of need for achievement on Entrepreneurship Attitudes at SMKN 1 Batang Hari. The research has hypothesis 1 (H1), which is: Need for achievement has a positive and significant effect on entrepreneurial attitudes at

Table 4 Multicollinearity Test Results

\begin{tabular}{llcc}
\hline \multicolumn{3}{c}{ Coefficients $^{\mathbf{a}}$} \\
\hline Model & Collinearity Tolerance & Statistics VIF \\
\hline $1 \quad$ Need for Achievement & 0,239 & 4,180 \\
& Locus of Control & 0,214 & 4,680 \\
& Entrepreneurship Attitudes & 0,408 & 2,453 \\
\hline
\end{tabular}

a.Dependent Variable: The Intention of Entrepreneurship

Table 5 Summary of Path Coefficients

\begin{tabular}{lcccc}
\hline \multirow{2}{*}{ Variabel } & Path Coefficients & \multicolumn{2}{c}{ Influence } & Total \\
\cline { 3 - 4 } & & Direct & Indirect & \\
\hline $\mathrm{X} 1-\mathrm{Y}$ & 0,269 & 0,269 & - & 0,269 \\
$\mathrm{X} 2-\mathrm{Y}$ & 0,525 & 0,525 & - & 0,525 \\
$\mathrm{X} 1-\mathrm{Z}$ & 0,236 & 0,236 & 0,062 & 0,298 \\
$\mathrm{X} 2-\mathrm{Z}$ & 0,484 & 0,484 & 0,102 & 0,586 \\
$\mathrm{Y}-\mathrm{Z}$ & 0,212 & 0,212 & - & 0,212 \\
$\varepsilon_{1}$ & 0,408 & 0,408 & - & 0,408 \\
$\mathcal{E}_{1}$ & 0,240 & 0,240 & - & 0,240 \\
\hline
\end{tabular}


SMKN 1 Batang Hari.

The results of the SPSS 25 output are related to the F-test and the t-test to determine the effect of need for achievement on entrepreneurship attitudes, which are provided in Table 5 and Table 6.

Based on Table 7, Sig. t of need for achievement is 0,006 . It is less than 0,05 , which means that the regression coefficient is significant. To test whether the contribution of the relationship between need for achievement to entrepreneurship attitudes is significant, the F-test is used which is shown in Table 5, where the value of $F=124,966$ with Sig. 0,006 . With a significance value less than 0,05 . It is considered that need for achievement has a significant and positive influence on entrepreneurial attitudes since the regression coefficient is positive, thus $\mathrm{H}_{1}$ is proven or accepted.

The second discussion is on influence of locus of control on entrepreneurship attitudes at SMKN 1 Batang Hari. Hypothesis $2\left(\mathrm{H}_{2}\right)$ is: Locus of control has a positive and significant effect on students' entrepreneurial attitudes at SMKN 1 Batang Hari in Gianyar Regency.

The results of the SPSS 25 output are related to the F-test and the t-test to determine the effect of locus of control on entrepreneurship attitudes, which are provided in Table 6 and Table 7.
Based on Table 7, Sig. $t$ for locus of control is 0,000 . It occurs to be less than 0,05 , which means the regression coefficient is significant. As seen in Table 6, F-test is used where the value of $F=124,966$ with Sig. 0,000 . With a significance value less than 0,05 and positive regression coefficient, it is found that locus of control has a significant and positive influence on entrepreneurial attitudes. The research proves that if the given locus of control is improved, the entrepreneurial attitude will increase. Hence, $\mathrm{H}_{2}$ is accepted.

Hypothesis $3\left(\mathrm{H}_{3}\right)$ of the research is: Direct need for achievement has a positive and significant effect on entrepreneurial intentions at SMKN 1 Batang Hari. The results of the SPSS 25 output are related to the F-test and the t-test to determine the effect of entrepreneurial attitudes on entrepreneurial intentions, as provided in Table 8 and Table 9.

Table 9 shows that Sig. $t$ of need for achievement is 0,002 , which means that the regression coefficient is significant. As seen in Table 8, the F-test finds that the value of $F$ is 180,828 with Sig. 0,000 . With a significance value less than 0,05 , it is found that need for achievement has a significant and positive influence on entrepreneurial intention, thus $\mathrm{H}_{3}$ is accepted.

Next, the research has hypothesis $4\left(\mathrm{H}_{4}\right)$, which is: Locus of control has a positive and significant

Table 6 F-Test Results for X1, X2, Z

\begin{tabular}{llccccc}
\hline \multicolumn{7}{c}{ ANOVA $^{\mathbf{a}}$} \\
\hline Model & Sum of Squares & df & Mean Square & F & Sig. \\
\hline 1 & Regression & 1033,995 & 2 & 516,997 & 124,966 & $0,000^{\mathrm{b}}$ \\
& Residual & 711,582 & 172 & 4,137 & & \\
& Total & 1745,577 & 174 & & & \\
\hline
\end{tabular}

a. Dependent Variable: The Intention of Entrepreneurship

b. Predictors: (Constant), Locus of Control, Need for Achievement

Table 7 T-Test results for X1, X2, Z

\begin{tabular}{llccccc}
\hline & \multicolumn{3}{c}{ Coefficients $^{\text {a }}$} \\
\hline Model & $\begin{array}{c}\text { Unstandardized } \\
\text { B }\end{array}$ & $\begin{array}{c}\text { Coefficients } \\
\text { Std. Error }\end{array}$ & $\begin{array}{c}\text { Standardized Coefficients } \\
\text { Beta }\end{array}$ & t & Sig. \\
\hline 1 & (Constant) & 10,129 & 1,746 & & 5,802 & 0,000 \\
& Need for Achievement & 0,191 & 0,069 & 0,269 & 2,759 & 0,006 \\
& Locus of Control & 0,409 & 0,076 & 0,525 & 5,391 & 0,000 \\
\hline
\end{tabular}

a.Dependent Variable: Entrepreneurship Attitudes

Table 8 F-Test Results for X1, X2, Y, Z

\begin{tabular}{llccccc}
\hline \multicolumn{7}{c}{ ANOVA $^{\mathbf{a}}$} \\
\hline Model & Sum of Squares & df & Mean Square & F & Sig. \\
\hline 1 & Regression & 1280,398 & 3 & 426,799 & 180,828 & $0,000^{\mathrm{b}}$ \\
& Residual & 403,602 & 171 & 2,360 & & \\
& Total & 1684,000 & 174 & & & \\
\hline
\end{tabular}

a. Dependent Variable: The Intention of Entrepreneurship

b. Predictors: (Constant), Entrepreneurship Attitudes, Locus of Control, Need for Achievement 
Table 9 T-Test Results for X1, X2, Y, Z

\begin{tabular}{|c|c|c|c|c|c|c|}
\hline \multicolumn{7}{|c|}{ Coefficients $^{\mathrm{a}}$} \\
\hline & & $\begin{array}{c}\text { Unstandardized } \\
\text { B }\end{array}$ & $\begin{array}{l}\text { Coefficients } \\
\text { Std. Error }\end{array}$ & $\begin{array}{c}\text { Standardized } \\
\text { Coefficients Beta }\end{array}$ & $\mathbf{t}$ & Sig. \\
\hline \multirow[t]{4}{*}{1} & (Constant) & 4,754 & 1,442 & & 3,297 & 0,001 \\
\hline & Need for Achievement & 0,164 & 0,053 & 0,236 & 3,079 & 0,001 \\
\hline & Locus of Control & 0,370 & 0,062 & 0,484 & 5,975 & 0,000 \\
\hline & Entrepreneurship Attitudes & 0,209 & 0,058 & 0,212 & 3,621 & 0,000 \\
\hline
\end{tabular}

a. Dependent Variable: The Intention of Entrepreneurship

effect on students' entrepreneurial intention at SMKN 1 Batang Hari. The results of the SPSS 25 output are related to the F-test and the t-test, as provided in Table 8 and Table 9 .

It is found out that Sig. $t$ of locus of control is 0,000 . It is less than 0,05 showing that the regression coefficient is significant. $F$ test is to find whether the contribution of the relationship between entrepreneurial attitudes to entrepreneurial intentions is significant. Table 8 shows the value of $\mathrm{F}$ is 180,828 with Sig. 0,000. With a significance value less than 0,05 , it is considered that locus of control has a significant influence on entrepreneurial intention, thus $\mathrm{H}_{4}$ is accepted.

Next, hypothesis $5\left(\mathrm{H}_{5}\right)$ is the research is: Entrepreneurial attitude has a positive and significant effect on students' entrepreneurial intention at SMKN 1 Batang Hari. The results of the SPSS 25 output are related to the F-test and the t-test to determine the effect of locus of control on entrepreneurial intention, as seen in Table 6 and Table 7.

Based on Table 9, Sig. $t$ of locus of control is 0,000 . It is less than 0,05 meaning that the regression coefficient is significant. As shown in Table 8, F-test proves that the value of F is 180,828 with Sig. 0,000 . With a significance value less than 0,05 , it is considered that locus of control has a significant influence on entrepreneurial intentions, thus $\mathrm{H}_{5}$ is accepted.

Hypothesis $6\left(\mathrm{H}_{6}\right)$ in the research is: Need for achievement with entrepreneurship attitude mediation has a positive and significant effect on students' entrepreneurial intention of SMKN 1 Batang Hari. Based on table 7 it is known that the value of the direct influence of need for achievement (X1) on entrepreneurial intention is $(Z) 0,269$. The indirect effect is equal to 0,298 which means that the value of the indirect effect is greater than the value of the direct effect. These results indicate that need for achievement (X1) through attitude (Y) indirectly has a significant effect on entrepreneurial intentions $(Z)$.

Lastly, hypothesis $7\left(\mathrm{H}_{7}\right)$ is: Locus of control with mediation of entrepreneurial attitudes has a positive and significant effect on students' entrepreneurial intentions of SMKN 1 Batang Hari. Table 7 shows that the value of the direct effect of locus of control (X2) on entrepreneurial intention is (Z) 0,525 and the indirect effect is 0,586 which means that the value of the indirect effect is greater than the value of the direct effect. This result indicates that locus of control (X2) through attitude (Y) indirectly has a significant influence on entrepreneurial intention $(Z)$.

\section{CONCLUSIONS}

The research finally comes up with conclusions: 1) Need for achievement has an influence on attitudes of class XI students at SMKN 1 Batang Hari, 2) Locus of control has an influence on attitudes of class XI students at SMKN 1 Batang Hari, 3) Need for achievement has an influence on class XI students' entrepreneurial intention at SMKN 1 Batang Hari, 4) Locus of control has an influence on the entrepreneurship intention of class XI students at SMKN 1 Batang Hari, 5) Attitudes have an influence on entrepreneurial intentions of class XI students at SMKN 1 Batang Hari, 6) Need for achievement experience through attitude indirectly has a significant influence on entrepreneurial intention of class XI students at SMKN 1 Batang Hari, and 7) Locus of control through attitude indirectly has a significant influence on entrepreneurial intention of class XI students at SMKN 1 Batang Hari.

The research results can be used as important information that the entrepreneurial intention must be owned by students to prevent the increasing number of unemployment, especially for SMK graduates. In addition, entrepreneurship teachers can arrange learning tools both from the syllabus, lesson plans, models learning and teaching methods to improve need for achievement, locus of control and student attitudes, so they have formed entrepreneurial intentions from an early age.

The research has limitations since it focuses on the problem of the influence of need for achievement and locus of control on the entrepreneurial intentions of students of SMK Negeri 1 Batang Hari through their attitudes. Moreover, the criteria for respondents is considered limited, so future researchers are suggested to extend and develop the criteria.

For future research, the research has a drawback since it is only carried out at one school at SMK Negeri 1 Batang Hari, so it is expected that further research is conducted at several other SMK in Batang Hari to produce more representative results. 


\section{REFERENCES}

Arifin, Y. (2018). Pengaruh harga minyak dunia, nilai tukar dan inflasi terhadap pertumbuhan ekonomi Indonesia. Economics Development Analysis Journal, 5(4), 474-483. https://doi.org/10.15294/ edaj.v5i4.22184.

Aulia, A. R. \& Yulianti, A. L. (2019). Pengaruh city branding "A Land of Harmony" terhadap minat berkunjung dan keputusan berkunjung ke puncak, Kabupaten Bogor. Jurnal Ilmiah MEA (Manajemen, Ekonomi, \& Akuntansi), 3(3), 67-75.

Blegur, A. \& Handoyo, S. E. (2020). Pengaruh pendidikan kewirausahaan, efikasi diri dan locus of control terhadap intensi berwirausaha. Jurnal Manajerial dan Kewirausahaan, 2(1), 51-61.

Chrismardani, Y. (2016). Theory of planned behavior sebagai prediktor intensi berwirausaha. Competence: Journal of Management Studies, 10(1), 90-103. https://journal.trunojoyo.ac.id/kompetensi/article/ view/3426/2535.

Ermawati, N., Soesilowati, E., \& Prasetyo, P. E. (2017). Pengaruh need for achievement dan locus of control terhadap intensi berwirausaha melalui sikap siswa kelas XII SMK Negeri se kota Semarang. Journal of Economic Education, 6(1), 66-74. https://journal. unnes.ac.id/sju/index.php/jeec/article/view/14704.

Fitria. F. \& Sudarmadi, D. (2019). Pengaruh sistem informasi akuntansi dan pengendalian internal terhadap kinerja karyawan PT. Beton Elemen Persada. Jurnal Akuntansi, Audit dan Sistem Informasi Akuntansi, 3(1), 1-13. http://journal.unla.ac.id/index.php/jasa/ article/view/455.

Handaru, A. W., Parimita, W., \& Mufdhalifah, I. W. (2015). Membangun intensi berwirausaha melalui adversity. Jurnal Manajemen dan Kewirausahaan, 17(2), 155166. https://doi.org/10.9744/jmk.17.2.165-176.

Imron, I. (2019). Analisa pengaruh kualitas produk terhadap kepuasan konsumen menggunakan metode kuantitatif pada CV. Meubele Berkah Tangerang. Indonesian Journal on Software Engineering (IJSE), 5(1), 19-28. https://doi.org/10.31294/ijse.v5i1.5861.
Ma'rifah, N. N. (2019). Pengaruh kebutuhan berprestasi, locus of control internal dan pengalaman kewirausahaan terhadap sikap kewirausahaan pada mahasiswa. Jurnal Pendidikan Ekonomi, Manajemen dan Keuangan, 3(1), 55-70. http:// dx.doi.org/10.26740/jpeka.v3n1.p55-70.

Murni, D. S. N. (2017). Hubungan internal locus of control dengan hubungan internal locus of control dengan intensi berwirausaha pada mahasiswa (Thesis). Universitas Muhammadiyah Malang.

Musdalifah \& Baharuddin, A. (2015). Pengaruh locus of control dan sikap berwirausaha terhadap intensi berwirausaha melalui kreativitas (Studi kasus pada ibu rumah tangga di Kecamatan DonriDonri Kabupaten Soppeng). Jurnal Ilmiah Ilmu Administrasi Publik, 5(2), 154-160. https://doi. org/10.26858/jiap.v5i2.1783.

Patanduk, C. Y., Rumate, V. A., \& Naukoko, A. T. (2019). Pengaruh investasi, tenaga kerja dan belanja pemerintah terhadap produk domestik regional bruto di provinsi Sulawesi Utara. Jurnal EMBA: Jurnal Riset Ekonomi, Manajemen, Bisnis dan Akuntansi, 7(3), 3988-3997. https://ejournal.unsrat.ac.id/index. php/emba/article/view/24914.

Rahayu, K. P. (2018). Menumbuhkan intensi berwirausaha pada mahasiswa manajemen Universitas Pamulang. Jurnal Pemasaran Kompetitif, 1(3), 125-135. https:// doi.org/10.32493/jpkpk.v1i3.1148.

Untu, Y. I. \& Widjaja, O. H. (2019). Pengaruh need for achievement dan self-efficacy terhadap entrepreneurial intention pada mahasiswa Fakultas Ekonomi Universitas Tarumanagara. Jurnal Manajerial dan Kewirausahaan, 1(2), 374-382. https://journal.untar.ac.id/index.php/JMDK/article/ view/5098/3183.

Wijaya, T., Nurhadi., \& Kuncoro, A. M. (2015). Intensi berwirausaha mahasiswa: Perspektif pengambilan risiko. Jurnal Siasat Bisnis, 19(2), 109-123. https:// doi.org/10.20885/jsb.vol19.iss2.art2. 